\title{
Vliv pregraduálního vzdělání na profesní počátky ve školní praxi pohledem začínajících učitelů
}

\author{
Ina Rajsiglová, KateŘina Přibylová
}

Abstrakt: Cílem prìspèvku je predstavit, jak sledovaní začinajicí učitelé vnímaji vliv pregraduálni prípravy na své prvni roky praxe a jaké lze na základě toho vysledovat možnosti zkvalitnèni prípravy budoucich učitelü.

Metody. Výzkumný vzorek se skládá ze trinácti začinajicich učitelu biologie/prírodopisu s praxi od jednoho do pèti let. Data byla ziskána prostrednictvím hloubkových polostrukturovaných rozhovorú a byla analyzována metodou zakotvené teorie.

$Z$ výsledkĩ vyplývá, že nejlépe byla hodnocena složka odborné biologické prípravy, nejvètši rezervy vykazovala složka pedagogicko-psychologická prèd oborově didaktickou. Obě složky pregraduálni prípravy vykazujici rezervy navrhovali respondenti posilit o pedagogické náslechy, aplikaci záżitkové výuky nebo zprostředkování výnky vysokoškolskými pedagogy či odborniky s reálnou pracovni zkušenosti ve školstvi. Hodnoceni pregraduálni prípravy bylo ovlivněno šokem $z$ reality vycházejicího z neprimèrèného očekáváni začinajicich učitelì.

Závèry. Za prínos této studie považujeme skutečnost, že pres jistou individuálnost názorù byly pozorovány určité trendy, které by bylo možné zohlednit prí prípravě vzdèlávacích programů budoucich učitelì, a dále to, že se nám podařilo rozkrýt kličové spojitosti mezi jednotlivými složkami pregraduálni prípravy ve vztahu ke zvládáni školni reality začinajicimi učiteli, což bylo vizualizováno abstraktním schématem v podobè tetraedru.

Kličová slova: začinajici učitel, problémy začinajicich učitelì, hodnoceni pregraduálni prípravy, možnosti úpravy pregraduální prípravy, školní realita.

Počátky v novém zaměstnání jsou náročné pro všechny profese a nejinak tomu je u profese učitele. Začínající učitel nastupuje do svého nového zaměstnání s určitými představami a očekáváním. Má plány, cíle a vysněné mety, které by rád uskutečnil. Ne vždy je však možné jejich naplnění, což začínající učitelé vníma- jí jako obtíž. Charakter obtíží může být různý, stejně jako jsou různé jejich př́ićiny. Ačkoli př́ićiny obtíží nelze vždy jednoznačně identifikovat, je možné je rozdělit do dvou hlavních kategorií. Podle Johnsona et al. (2014) lze do první z nich řadit nevhodnou či nedostatečnou podporu ze strany vedení a kolektivu školy. Do druhé 
kategorie pak řadí pregraduální prrípravu neposkytující začínajícím učitelům veškeré potřebné dovednosti, viz např. Jensen et al. (2012), což vzbuzuje zkreslené představy o chodu školy; to může vést až k šoku z reality a odchodu ze školství (Friedman, 2000; Johnson et al., 2014). A právě druhé kategorii př́čin obtíží bude věnována tato studie.

Téma začínajících učitelů je $\mathrm{v}$ české i zahraniční odborné literatuře hojně řešeno (např. Darling-Hammond, 2003; Swabey, Castleton \& Penney, 2010; Šimoník, 1995; Švec, 2006), nicméně v kontextu celostátně řešené problematiky poddimenzovanosti školství a odchodovosti (nejen) začínajících učitelů do jiných profesních sfér považujeme zkoumání v této oblasti za stále aktuální. Tato studie se proto zabývá otázkou, nakolik jsou začínající učitelé připraveni zvládat výuku v kontextu pregraduální přípravy. Naším cílem je odhalit a prozkoumat ta místa pregraduální př́ípravy, která vykazují problematické aspekty, a současně prezentovat návrhy začínajících učitelů na podporu takové pregraduální přípravy, která začínajícím učitelům umožní hladší vplynutí do školní reality a integraci s ní.

\section{TeORETICKÝ PŘEHLED}

\subsection{Začínající učitel v kontextu profesního vývoje a obtíží s ním spojenými}

Doba, po kterou je učitel učitelem začínajícím, není pevně určena. Někteří autoři specifikují fázi začínajícího učitele délkou praxe (např. Berliner, 1989). Často jsou za začínající učitele považováni učitelé s praxí od jednoho do pěti let. Tento časový rozsah je důsledkem chápání pojmu „začínající učitel“ jako jedné z fází profesního vývoje učitele a skutečnosti, že existuje nespočet modelů profesního vývoje, které nahlížejí na fázi začínajícího učitele $\mathrm{z}$ různých úhlů pohledu. Jiní autoři (Burke, Christensen \& Fessler, 1984; Kugel, 1993; Richardson \& Placier, 2001) tuto fázi charakterizují spíše prostřednictvím schopností a dovedností učitele, jelikož si uvědomují, že profesní vývoj je komplexní proces ovlivňovaný nespočtem faktorů. Podle Daye (1999, s. 29), Richardsonové a Placierové (2001, s. 907) či Fesslera et al. (1984) tyto faktory, mezi které patří předchozí zkušenosti, pregraduální př́iprava, profesní kompetence (k nim napřr. Gillernová, 2003; Shulman, 1987; Spilková, 2004), školní podmínky, v nichž učitel působí, a podobně, stojí za individuálním vývojem každého $\mathrm{z}$ učitelů a kvůli nim nelze stanovit přesné časové rozpětí začátečnického období. Objektivní stanovení fáze vývoje, ve které se začínající učitel nachází, je o to těžší, vezmeme-li v potaz, že s rostoucími zkušenostmi mají začínající učitelé sklon se podceňovat (Dropkin \& Taylor, 1963; Choy et al., 2013).

\subsection{Hodnocení pregraduální přípravy začínajícími učiteli a návrhy na změnu}

Z literatury lze vysledovat, že začínající učitelé nejčastěji označují za nej- 
silnější stránku pregraduální přípravy odbornou výuku své aprobace (Hesson, 2016; Kalhoust \& Horák, 1996; Salazar Noguera \& McCluskey, 2017; Vítečková \& Gadušová, 2015). Naopak za nejslabší místo je všeobecně považována pedagogicko-psychologická složka pregraduální př́ípravy (Šimoník, 1995; Vítečková \& Gadušová, 2015). V některých př́padech je důvodem nevyhovující pedagogicko-psychologické př́pravy nevhodný obsah předmětů (Chesley \& Jordan, 2012; Salazar Noguera \& McCluskey, 2017; Sandoval-Lucero et al., 2011), nicméně častěji se jedná o nevyhovující formu výuky - v určité podobě až antididaktickou, tj. prezentující to, jak by práce se žáky vypadat neměla (Vašutová et al., 2008, s. 177) -, která byla převážně teoretická bez praktického přesahu (Buchanan, 2002; Salazar Noguera \& McCluskey, 2017; Švec, 2006) a byla vyučována učiteli bez praktických zkušeností s reálnou školní výukou (Chesley \& Jordan, 2012). Začínajícím učitelům tak byl představován falešný obraz reality (Salazar Noguera \& McCluskey, 2017), který vedl $\mathrm{k}$ tomu, že si učitelé jednak vytvářeli zkreslená očekávání před nástupem do praxe (Buchanan, 2002) a jednak pak $\mathrm{v}$ praxi nebyli pripraveni na to, co mohou od svých žáků či jejich rodičủ čekat (Swabey et al., 2010).

Začínající učitelé dále poukazují na to, že teoreticky nabyté poznatky nejsou schopni v praxi využít (Buchanan, 2002), proto si častěji váží předmětů, v nichž byla výuka realizována prakticky, at už s př́iklady dobré praxe, diskuse- mi či pomocí mikrovyučování (Chesley \& Jordan, 2012; Rajsiglová \& Přibylová, 2020; Salazar Noguera \& McCluskey, 2017; Sandoval-Lucero et al., 2011). Praktickým nácvikem a zažitím si určité situace je možné efektivněji eliminovat chyby, kterých se budoucí učitelé dopouští i přes předchozí dostatečný teoretický výklad (Rajsiglová, 2019).

Z literatury dále plyne, že začínající učitelé se $\mathrm{v}$ rámci pregraduální prrípravy setkali jen se zlomkem neočekávaných situací, které pak ve skutečné praxi museli řešit, a ani $v$ rámci teoretické výuky jim zpravidla nebyly poskytnuty relevantní rady či tipy pro řešení těchto situací (Salazar Noguera \& McCluskey, 2017). Navrhovali proto navýšení pedagogických praxí, případně náslechů (Buchanan, 2002), a také častější začleňování efektivních tipů a nápadů pro jednání v určitých situacích, kterými by se mohli inspirovat (Rajsiglová \& Přibylová, 2020; Salazar Noguera \& McCluskey, 2017).

Z práce Šimoníka (1995) vyplývá, že existuje pozitivní korelace mezi vnímanými obtížemi a hůře vnímanou úrovní přípravy na ně. Hledání cest jak překonat izolovanost pregraduální př́pravy od školní reality je trend, který zaznamenáváme $\mathrm{v}$ publikacích řady autorů (Píšová \& Hanušová, 2016; Píšová et al., 2011; Spilková \& Vašutová, 2008, aj.). Naší studií se snažíme tento trend podpořit a navrhnout možné směřování, nebot' problematiku potíži začínajících učitelů ve vztahu k pregraduální prrípravě a školní praxi považujeme za stále aktuální a diskusi k ní za potřebnou. 


\section{VÝZKUMNÁ ČÁST}

\subsection{Výzkumné otázky}

Nástup začínajícího učitele do jeho prvního zaměstnání s sebou přináší mnohá úskalí a obtíže. Jak uvádí Píšová a Hanušová (2016) začínající učitelé jsou skupinou, která je předčasným odchodem ze zaměstnání ohrožena nejvíce. Podle Darling-Hammondové (2003) má na odchodovost začínajících učitelů vliv mimo jiné kvalita pregraduální př́ípravy. Zkvalitnění pregraduální přípravy tak může být vedle dalších opatření, jako např. probíhající zvyšování platů učitelů, jedním z opatření, jak zabránit předčasnému odchodu nováčků ze školství. Na základě těchto úvah byla stanovena základní výzkumná otázka: Jak začínající učitelé vnímají vliv pregraduální př́pravy na průběh jejich prvních let praxe?

Tato široká otázka, což je pro kvalitativní výzkum charakteristické, byla dále po reformulaci (blíže viz níže) - rozčleněna do dvou specifických výzkumných otázek:

1. Jaké názory a postoje formulují začínající učitelé ve vztahu k absolvované pregraduální př́pravě?

2. Jaká podoba pregraduální prípravy $\mathrm{v}$ dílčích oblastech by mohla ulehčit počátky začínajícím učitelům?

Pro zodpovězení výzkumných otázek byl zvolen kvalitativní výzkum popsaný v následující kapitole.

\subsection{Metodologie výzkumu}

Za způsob sběru dat byl zvolen hloubkový polostrukturovaný rozhovor, který byl vytvořen rozvinutím výzkumných otázek. Takto vzniklo schéma prvního souboru otázek, přičemž se jednalo o 14 otevřených otázek, které se týkaly široce vymezené výzkumné otázky s obsahovým zaměřením na: motivaci ke studiu učitelství, přínos pregraduální přípravy ve vztahu k reálné školní praxi, vnímané podpory ze strany VŠ vyučujících, vnímané podpory ze strany pracoviště, resp. základní či stř̌ední školy, dodatečné vzdělávací potřeby apod. Otázky byly testovány v rámci předvýzkumného šetření na dvou respondentech. Cílem předvýzkumného šetření bylo ověrit srozumitelnost otázek a zjistit, zda nebyla opomenuta některá témata potřebná $\mathrm{k}$ zodpovězení výzkumných otázek. Nové informace, které z rozhovorů po jejich prvotní analýze prrirozeně vzešly, sloužily pro úpravu otázek první verze rozhovoru a vedly $\mathrm{k}$ finálnímu souboru otázek. Daný proces prisspěl také k reformulaci základní výzkumné otázky. Původním záměrem bylo zmapovat pregraduální př́ípravu jako celek a vysledovat hlavní trendy přínosné pro praxi začínajících učitelů, nicméně při práci $s$ daty se ukázalo jako nosné porovnat jednotlivé složky pregraduální prŕípravy a zohlednit jejich prolínání.

Reformulovaná základní výzkumná otázka zní: Jak začínající učitelé nahližzejí na absolvovanou pregraduální prrípravu $\mathrm{v}$ jejích dílčích složkách pro potřeby hladkého průběhu prvních let $\mathrm{v}$ reálné školní praxi?

Rozhovory $s$ učiteli byly realizovány na školách, kde působili, v průběhu května až prosince 2017, konkrétně v odbor- 
ných učebnách biologie či jejich kabinetech, a následně jsme se $\mathrm{k}$ respondentům $\mathrm{v}$ prrípadě potřeby během první poloviny roku 2018 vracely. Vedení rozhovorů ve známém prostředí zajistilo zvýšení pohodlí a snížení nervozity respondentů, což doporučuje také Miovský (2006, s. 161). Rozhovory byly nahrávány na diktafon a přepsány do podoby textu. Učitelům byla zaručena jejich anonymita přidělením náhodně zvolených pseudonymů. Průměrná délka realizovaných rozhovorů byla 76 minut, prepis jednoho rozhovoru pak měl průměrně 40 stran textu; celkový datový soubor čítal 424 stran textu.

Výzkumná práce trvala 19 měsíců a byla rozčleněna do tří fází: prrípravné (studium literatury, formulování výzkumného problému a vytváření výzkumného plánu), realizační (sběr dat) a analytické (tematická analýza dat), přičemž fáze realizace a analýzy rozhovorů se navzájem prolínaly a nebyly tak od sebe odděleny. Primárním výstupem byla deskripce tématu a prvotní konceptualizace, na což navazovala další, čtvrtá fáze, kterou charakterizuje proces přetvoření deskriptivního výstupu do podoby zakotvené teorie. Stejně jako se nejednalo o lineární proces mezi druhou a třetí fází, docházelo $\mathrm{k}$ překryvu i mezi třetí a čtvrtou fází, nebot z důvodu dosbírávání dat se proměňoval také paradigmatický model (blíže viz dále), přičemž docházelo ke konstantní komparaci analyzovaných dat (neustálému porovnávání dat $s$ daty, s teoretickými kategoriemi a těmi mezi sebou).

Pro analýzu dat, která vyplynula z realizovaných rozhovorů, byla využita metoda zakotvené teorie (Strauss \& Corbinová, 1999). Princip zakotvené teorie jsme vybraly z několika důvodů. Hlavním důvodem je, že se jedná o metodu zaměřenou na studium interakcí a procesů. $\mathrm{K}$ její volbě nás dále vedlo uvědomění si, že literatura mapuje dané téma $\mathrm{v}$ mnoha ohledech a nahlíží na potřeby začínajících učitelů $s$ deskriptivním nadhledem, nenabízí ale vedle diskusí a polemik možnosti řešení situace přímo od začínajících učitelů, tedy s ohledem na jejich aktuální potřeby, počáteční těžkosti i úspěchy, o které se mnohdy nemají zpětně (ve vztahu $\mathrm{k}$ pregraduální př́ípravě a původním vysokoškolským vyučujícím) s kým podělit. A v neposlední řadě nás $\mathrm{k}$ výběru této metody vedla $\mathrm{v}$ českém prostředí explicitní neexistence teorie deklarující souvislost mezi úspěšným startem $\mathrm{v}$ počátcích profesní kariéry začínajících učitelů a jejich pregraduální prípravou. Usilovaly jsme o komplexní zmapování vhledu respondentů do těžkostí, které jim každodenní školní situace $\mathrm{v}$ praxi př́ináší, jejich snahy o vyřešení daných obtíží, a to $v$ souvislosti $s$ vlivem pregraduální prrípravy. $S$ ohledem na uvedené se nám princip zakotvené teorie jevil jako odpovídající inherentní metodologický nástroj, umožňující nezůstat u deskripce a zároveň nabízející identifikovat proměnné a jejich vztahy vůči sobě navzájem a v závěru postulovat kauzální model jevu.

Třemi druhy kódování - otevřeným, axiálním a selektivním - jsme dospěly k centrální kategorii jevu, kterým bylo v našem případě „vnímání pregraduální př́pravy“. V rámci otevřeného kódování 
jsme data prepsaly a analyzovaly metodou tužka-papír, kterou jsme upřednostnily před počítačovým softwarem $\mathrm{z}$ důvodu ideální dostupnosti a $\mathrm{v}$ neposlední řadě proto, že je to metoda, která pomáhá lépe si napsané pamatovat, což jsme ocenily při revizi kódování.

V prvním kroku jsme nezávisle na sobě analyzovaly první tři rozhovory metodou induktivního otevřeného kódování, následně byly kódy porovnávány a diskutovány a byl vytvořen jednotný kategoriální systém, který jsme využily pro následnou analýzu dat. Vzhledem k postupnému doplňování datového souboru jsme podrobily autorskému nezávislému kódování celý výsledný soubor třinácti rozhovorů a v závěru na základě recenzních posudků opětovně podrobily datové soubory reanalýze, čímž jsme dospěly $\mathrm{k}$ finálnímu souboru kategorií. Naše kódování vychází z deduktivně-induktivní povahy kódování. V první úrovni jsme formulovaly indikátory dané datovými úryvky. Ve druhé úrovni pak byly koncepty charakteristické kódy (např. úryvek „Musim je zvednout ze židle a zapojit dalši smysly. Takže neformálni vzdèláváni mi pomohlo v tom najit si metody a tunit ty témata tak, aby se do toho zapojili minimálně pohybem. Aby je to bavilo. “byl kódován jako „využívání zkušeností z mimoškolní činnosti“.), čímž jsme zachovávaly dvouúrovňový charakter kódů. Následně jsme kódy ve třetí úrovni zařazovaly do kategorií analyzovaných jako proměnné (zvolený př́klad spadá do kategorie „způsob řešení"; další kategorie viz kauzální model - viz obr. 2 dále $\mathrm{v}$ textu).
Axiálním kódováním jsme navázaly na kódování otevřené, přičemž jsme vytvořily paradigmatický model (viz obr. 1), který nám sloužil jako pomůcka $\mathrm{k}$ vytvoření spojení mezi jednotlivými (sub)kategoriemi a prostředek ke třídění dat. Následné selektivní kódování vedlo ke klíčové kategorii, kterou v našem př́padě představuje „zvládání školní reality (viz obr. 2). Selektivní výsledky kódování navázaly na výsledky axiálního kódování, což nám umožnilo opustit paradigmatický model a vytvořit následný kauzální model vlivu vnímání vlastní úspěšnosti při zvládání školní reality ve vztahu k hodnocení jednotlivých složek pregraduální př́ípravy (viz obr. 2).

Postupným procesem výše popsaného kódování vznikl analytický př́běh, který bude popsán dále.

\subsection{Zpětné zakotvení teorie a další techniky kontroly kvality výzkumu}

Pro potřeby tohoto výzkumu uvádíme techniky, které jsme využily jako garanci kvality realizovaného výzkumu; jsou jimi důvěryhodnost, hodnověrnost, potvrditelnost a zpětné zakotvení teorie.

V souladu s Lincolnovou a Gubou (in Hendl, 2005) podporujeme důvěryhodnost délkou trvání studie, což bylo 19 měsíců, príičemž po celou tuto dobu jsme byly v kontaktu nejen s respondenty výzkumu, za kterými jsme se $\mathrm{v}$ prŕpadě potřeby opakovaně vracely, a to bud' osobně, či prostřednictvím e-mailové korespondence, ale i s dalšími absolventy, kteří do výzkumu nebyli zapojeni. Ti pomáhali dokreslit 
zkoumané prostředí a potřeby začínajících učitelů $s$ ohledem na pregraduální př́ípravu a zároveň sloužili jako zpětnovazebné vodítko pro reflexi vznikajících závěrů a pro kontrolu správného rozklíčování tří dimenzí pohledů na potíže začínajících učitelů (viz dále).

Hodnověrnost, nahrazující $\mathrm{v}$ kvalitativním výzkumu reliabilitu, jsme sytily v podobě triangulace, kdy jsme celý datový korpus kódovaly nezávisle na sobě a následným konsenzuálním přístupem daly vzniknout jednotlivým kategoriím. Vedení rozhovorů, u nichž jsme z počátku participovaly obě, zahrnovalo vnitřní triangulační mechanismy, jež byly zastoupeny $\mathrm{v}$ podobě návratných otázek a jejich variací, abychom ošetřily př́padné nejednotnosti ve výpovědích respondentů.

$\mathrm{V}$ neposlední řadě kritérium potvrditelnosti obhajujeme co nejpřesnějším popisem našeho výzkumného šetření a dále i výpověd'mi respondentů (jsou zaznamenané kurzívou $\mathrm{v}$ empirické části textu), aby čtenár mohl osobně posoudit prŕípadnost interpretace.

V souladu s požadavky Strausse a Corbinové (1999) jsme v závěrečné fázi výzkumu přistoupily ke zpětnému zakotvování teorie, což přispělo $k$ dodatečným úpravám výsledného rozkreslení modelu tetraedru (viz dále) a zároveň nás ujistilo o vhodnosti třídění typologie respondentů s ohledem na jejich optimální zařazení $\mathrm{k}$ jednomu ze způsobů nahlížení na pregraduální přípravu. Klíčové charakteristiky a dimenze sledované u respondentů pro potřeby vznikající zakotvené teorie a její zpětné zakotvování viz př́loha.

\subsection{Výzkumný vzorek}

Metoda zakotvené teorie je metoda práce $s$ daty, která nespočívá pouze $\mathrm{v}$ jejich analýze, ale i v jejich správném výběru. Výzkumník by se měl snažit, aby jeho vzorek respondentů byl co možná nejpestřejší a on tak postřehl nejen typické, ale i více specifické představitele výzkumného vzorku, na které cílí. Jen tak je totiž možné vytvořit analytický příběh, který bude platit pro jakéhokoli představitele skupiny, na kterou se výzkum zaměřuje. Vzorek respondentů byl proto vytvářen gradačně, jak doporučují např. Glaser a Strauss (2006, s. 45). V první vlně sběru respondentů byla stanovena kritéria pro jejich výběr, která měla zaručit, že se bude jednat o začínající učitele biologie s odpovídající klasifikací. Kritérii byla minimálně roční a maximálně pětiletá délka praxe na základní či střední škole s výukou biologie a dále úplné ukončení magisterského studia učitelského oboru se zaměřením na biologii a další libovolný aprobační předmět.

Zároveň bylo myšleno na podmínku pestrosti vzorku, která s sebou přináší datovou nasycenost (Glaser \& Strauss, 2006, s. 60), proto bylo záměrem, aby učitelé pocházeli z různých vysokých škol, a tedy i krajů. $\mathrm{V}$ první vlně byly s ohledem na dojezdové možnosti autorek vybrány tř̌i kraje (Jihočeský, Jihomoravský a Vysočina), v rámci nichž byli e-mailem kontaktováni všichni ředitelé základních a středních škol, kde se alespoň jeden rok vyučuje předmět biologie. Tímto způsobem bylo získáno devět respondentů, a to 
z Pedagogické fakulty Jihočeské univerzity (dále jen PF JU), Pedagogické fakulty Západočeské univerzity (FPE ZČU), Pedagogické fakulty Univerzity Karlovy (PedF UK), Př́rodovědecké fakulty Masarykovy univerzity (dále jen PřF MU) a Př́rodovědecké fakulty Univerzity Palackého (dále jen PřF UPOL). V rámci první vlny sběru byli do výzkumného vzorku zařazeni také čtyři začínající učitelé z Přírodovědecké fakulty Univerzity Karlovy (dále jen PřF UK), a to na základě osobního kontaktu respondentů a autorek.

Aby pestrost dat byla dána nejen počtem vysokých škol, odkud respondenti pocházeli, ale také odlišně zkušený- mi učiteli, snažily jsme se, aby v těchto ohledech bylo jejich zastoupení např́ić vzorkem rovnoměrně rozložené. Byla tak zahájena druhá vlna sběru respondentů, v rámci níž bylo cíleno na začínající učitele s délkou praxe jeden rok a čtyři až pět let a zároveň na takové, kteří vystudovali jinou vysokou školu, než sytila první vlna výběru, ze kterých jsme již zástupce měly. Výsledný výzkumný soubor obsahoval šestnáct začínajících učitelů, se kterými byly postupně realizovány předvýzkumné i výzkumné rozhovory. Vzhledem $\mathrm{k}$ tomu, že se u devátého až desátého respondenta začala data opakovat, byl u třináctého učitele sběr dat ukončen.

Tab. 1. Stručné charakteristiky začínajících učitelů $(Z U)$, kteří byli vybráni do výzkumu

\begin{tabular}{|c|c|c|c|}
\hline $\begin{array}{l}\text { Kategorie podle } \\
\text { let praxe }\end{array}$ & Jméno (pseudonym) & Absolvovaná VŠ & $\begin{array}{c}\text { Typ školy, na které ZU } \\
\text { působil/působí }\end{array}$ \\
\hline \multirow{4}{*}{1 rok } & Radek & PřF UPOL & základní škola \\
\hline & Pavla & PF JU & základní škola \\
\hline & Jakub & PF JU & základní škola \\
\hline & Marie & PřF UK & gymnázium \\
\hline \multirow{5}{*}{ 2-3 roky } & Julie & PF JU & gymnázium \\
\hline & Karolína & PřF MU & gymnázium \\
\hline & Martina & FPE ZČU & základní škola \\
\hline & Kristýna & PřF UK & základní škola \\
\hline & Jitka & PřF UK & základní škola \\
\hline \multirow{7}{*}{$4-5$ let } & \multirow{2}{*}{ Monika } & \multirow{2}{*}{ PedF UK } & SOŠ zdravotní \\
\hline & & & základní škola \\
\hline & Renata & PedF UK & základní škola \\
\hline & Klára & FPE ZČU & základní škola \\
\hline & \multirow{3}{*}{ Marek } & \multirow{3}{*}{ PřF UK } & základní škola \\
\hline & & & gymnázium \\
\hline & & & soukromé gymnázium \\
\hline
\end{tabular}


Kompletní seznam všech respondentů $s$ jejich stručnými charakteristikami uvádíme v tabulce 1 .

\section{VÝSLEDKY VÝZKUMNÉHO ŠETŘENÍ}

$\mathrm{V}$ této kapitole prezentujeme a interpretujeme nálezy vzešlé $\mathrm{z}$ analýzy popsané výše.

Shledaly jsme, že názory sledovaných učitelů se odvíjejí zejména od šoku vyplývajícího ze střetu se školní realitou. Tento střet se tak stal integrujícím prvkem celého výzkumu. Abychom rozklíčovaly př́činy šoku, podporovaly jsme respondenty $\mathrm{v}$ přemýšlení o tom, jakou roli hrála pregraduální příprava $v$ jejich více či méně úspěšných počátcích. Také jsme $\mathrm{v}$ rámci vyhodnocování hledaly důvody odlišných odpovědí mezi jednotlivými začínajícími učiteli v př́ípadě, že př́inášely nová zjišsění, a to i mimo oblast jejich vysokoškolské př́pravy (např. s ohledem na mimoškolní činnosti, motivaci či druh školy, kde začínající učitelé působili).

$\mathrm{Na}$ základě analyzovaných dat byl sestaven paradigmatický model (obr. 1), který se stal podkladem pro vytvoření kostry analytického prríběhu.

\subsection{Kauzální model}

V této kapitole popíšeme kauzální model, odrážející kategorie paradigmatického modelu, vlivu pregraduální prrípravy v souvislostech $s$ více či méně úspěšnými počátky začínajících učitelů a ohlédnutí těchto učitelů za absolvovanou pregraduální príípravou.

Respondenti měli různou vstupní míru osobnostních předpokladi̊ a motivace jít studovat učitelství v aprobaci s biologií či prrírodopisem a stát se učitelem: „Od malička jsem si hrála na učitelku a chtěla jsem učit." (Klára); „Mè docela v tom motivoval vyučujici na stredni - biologár r. ... protože se mi libilo, jak učil.“ (Marie); „Mě baví pracovat s détma. “(Jitka); „... Tak výuka to prímo nebyla, ale docela dlouho jsem se angažovala ve skautskym oddilu." (Karolína); "Já jsem piovodně nechtěla bejt učitelka... Mĩj cil byl... jit na medicinu a stát se nějakým lékařem, ale... vlastně moje prïiimaci zkoušky tedy nedopadly, nepríjali mè, méla jsem pedagogiku danou jako takovou, jak se ř̀iá, ,záchranu." (Renata)

Měli také různá očekávání ve vztahu k budoucímu povolání: „Já jsem si myslela, že prijidu do školy a všichni budou nadšeni, že jim někdo jde... prèedávat vědomosti, do-

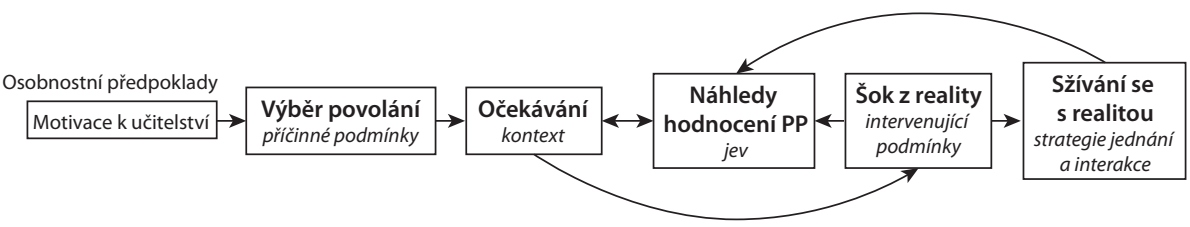

Obr. 1. Paradigmatický model pro vnímání pregraduální přípravy (PP) a podpory školního prostředí začínajících učitelů 
vednosti.“"(Klára); „Měl jsem obavy, jak mě prijme ten kolektiv, jak mě prijmou ty dèti." (Jakub)

Daná očekávání $\mathrm{v}$ nich posilovala či měnila vlastní absolvovaná pregraduální př́prava na zvolené vysoké škole. Žádný učitel ze sledovaného souboru se následně přes množství předmětů vedoucích $\mathrm{k}$ přípravě na budoucí povolání nevyhnul šoku v podobě reálného střetu se školní realitou: „... oni té zkoušeji, co vydržišs, co povoliš, jak moc seš prísná... “(Klára); „Ten prvni rok byl krušnej. Za prvý jsem si všechno musela pripravit. Nic jsem nedostala zadarmo." (Martina); „Spiš to bylo náročný kvůli tomu papirování, protože jako papirování třidního učitele, to je fakt hrüza. ... Člověk nějak vyučuje a nejsem pripravená na takový to, že on tady najednou začne něco vykřrikovat a vztekat se..." (Kristýna); „Nejhorši bylo to vymyslet, jakým stylem budu učit... Jestli budu mit $v$ téch hodinách prezentaci nebo budu mit výklad.“ (Karolína); „A jenom udržet tu pozornost tèch dètí, takže vic než o výuce je to občas o výchové." (Jitka); „Hlavné jeśtě vybrat z tý látky jako to, co je opravdu důležitý pro ně." (Monika)

To, jak jednotliví učitelé přistoupili k tomu, aby počáteční šok eliminovali a co nejlépe se vypořádali s danou školní realitou, a jak úspěšně či neúspěšně zvlá- dali řešit obtíže, se pak odráželo $v$ jejich reflexi, $\mathrm{v}$ krajních př́padech až $\mathrm{v}$ kritice pregraduální př́pravy. Hodnocení pregraduální př́ípravy tak není statický jev, nýbrž dynamický proces, ve kterém se jednotlivé kategorie ovlivňují. To dává začínajícím učitelům prostor $\mathrm{k}$ reflexi, resp. hodnocení pregraduální př́ípravy (obr. 2).

Výše popsané považujeme za kostru naší analýzy, přičemž to, jak se sledovaní učitelé vyrovnávali s počátky reálné školní praxe, vykrystalizovalo ve trri způsoby nahlížení na pregraduální přípravu.

\subsection{Tr̛̃i zpưsoby nahlížení na pre- graduální př́ípravu}

Všem respondentům byla položena otázka, v jakých aspektech jim pomohla či nepomohla pregraduální prríprava ve vztahu k počátkům jejich školní praxe. $Z$ analýzy dat lze interpretovat, že nahližení na pregraduální prŕípravu ovlivňuje to, jak sami začínající učitelé vnímají vlastní úspěšnost ve zvládání školní reality. Po nástupu začínajících učitelů do praxe se všichni učitelé zmiňovali o problému týkajícím se neschopnosti řešit žákovskou nekázeň.

Analýzou výzkumu jsme pak ve vztahu $\mathrm{k}$ řečenému a v souladu s obr. 3 vysle-

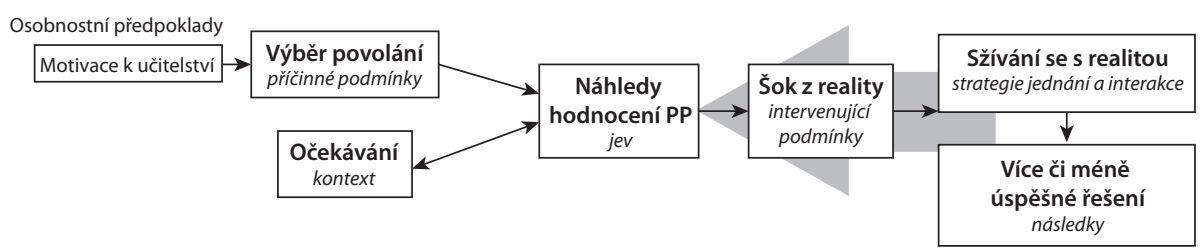

Obr. 2. Kauzální model 
dovaly tři okruhy hodnocení pregraduální prrípravy, přičemž $\mathrm{v}$ následujícím textu uvedeme do vztahů krajní prrípady zvládání a nezvládání školní reality, abychom je následně vizualizovaly a doplnily o zbývající okruh.

\subsubsection{Akcent na pedagogicko-psy- chologickou složku pregraduální př́ípravy}

$\mathrm{V}$ př́padě, že respondenti nezvládají uspokojivě řešit otázky spojené se školní realitou (viz obr. 3-I), akcentují v pregraduální prrípravě nedostatečnosti $\mathrm{v}$ pedagogicko-psychologické př́ípravě a rezervy vnímají také $\mathrm{v}$ nízkém počtu pedagogických praxí, které by je naučily nahlížet na konfliktní situace žáků a jejich nekázeň. Ve vlastní školní praxi narážejí na obecné otázky pedagogiky a psychologie, nikoli na otázky didaktické ve vztahu ke způsobu vedení vyučovací hodiny.

Napříc všemi analyzovanými výpověd'mi respondentů zaznívalo negativní hodnocení transmisivního způsobu předávání poznatků v rámci pedagogicko-psychologického bloku, a to kvůli nezapamatovatelnosti zprostředkované teorie. Druhým důvodem byla skutečnost, že poznatky, které studenti pouze přebírali z vysokoškolské výuky, ne vždy fungovaly, což ještě více umocňovalo kritické nazírání začínajících učitelů na pedagogicko-psychologickou př́pravu. „Obecný zásady ... když oni křič́, nekričet na ně. No, ale když oni řvou a vy tady potichu: ,Uklidnète se..., já bych chtéla dál vykládat.' No tak jako taky se musi zarvat na nè,... oni zpozorni." (Pavla)
Zároveň učitelé mluvili o vzdálenosti této složky vysokoškolské př́pravy od reality. Podle jejich názoru prohlubovali vzdálenost od reality vyučující bez osobní zkušenosti s kontextem reálného školního prostř̌edí. Právě ti byli nejednou zdrojem falešných očekávání ohledně chování žáků: „... mi prǐšlo, že spousta lidi z tý pedagogiky a psychologie... nikdy neučili na základni škole, ... nebyli na základce dvacet let, a neví..., co ty děti můžou dělat." (Julie)

$S$ přihlédnutím k danému, respondenti vytýkali výuce, že namísto integrovaného pojetí pedagogicko-psychologických disciplín, propojeného se školní realitou a s př́klady dobré praxe, převládá pojetí klasické, kdy se $\mathrm{v}$ rámci studia dovídali o možnostech na základě frontálně vedené přednášky. Ve výuce postrádali oblasti týkající se činností učitele a rozbor těchto činností i možnosti řešení školních situací. Absentovala témata řešení neočekávaných situací, zejména kázeňského charakteru, se kterými se začínající učitelé v počátcích museli potýkat, nebyli připraveni na jednání se žáky ani s rodiči: „K čemu mi to je, vèdèt nèjaký typy osobnosti a... teorie pedagogiky,... když potom ve finále nedokážu vyřesit situaci, která je naprosto běžná..." (Monika); "Problém podle mého názoru byl $v$ odděleni pedagogiky a psychologie... Spousta predmètù, spousta odborností, ale presah do praxe nulovej... Jak prostě komunikovat, jak s téma dètma, tak s téma rodičema, nás nikdo neučil." (Jakub)

Naopak kladně byly hodnoceny předměty využívající zážitkovou výuku, která je založena na reflektivním učení 
a př́kladech dobré praxe. Učitelé, kteří ji absolvovali, uváděli, že v konkrétních situacích se jim poznatky „živě“ vybavovaly, a proto si této formy výuky cenili. "Ta psychologie byla o néco silnéjš́ než ta pedagogika, protože... v té pedagogice... třeba ty alternativni školy a podobně... mi úplnè nějak neprijide, že by se to dalo extra použit... V té psychologii mi prijde, že třeba když vidim nèjakýs studenty, tak premejšlim, jak to s nima je... jestli v té trídè neni sikana a podobnè..." (Marie)

Výpovědi lze číst tak, že začínající učitelé v profesních počátcích silně reflektují to, zda je vysokoškolský učitel odborník, a zároveň i to, zda měl adekvátní zkušenost se školní realitou např. v podobě spektra metod (ne)využívaných v předmětech vysokoškolského studia. Respondenti dále formulují požadavek na takový způsob výuky, který by konfrontoval studenty s konkrétními výukovými a kázeňskými situacemi, které by společně $s$ vyučujícími rozebírali a nacházeli možnosti řešení těchto situací.

\subsubsection{Akcent na (oborově) didaktic- kou složku pregraduální př́pravy}

$\mathrm{V}$ př́ípadě, že respondenti zvládají uspokojivě řešit otázky spojené se školní realitou (viz obr. 3-III), reflektují oborově didaktickou stránku pregraduální přípravy, kterou by rádi podpořili větším množstvím času stráveného na pedagogických praxích, aby se hlouběji seznámili s procesy a funkčními rysy, které vyučovací hodiny nabízí.

Začínající učitelé učící prvním rokem se zmiňovali o rezervách $\mathbf{v}$ projekci uči- va a zejména pak o obtížích ve výběru vhod né výukové metody a formy: "Nejhorsí bylo to vymyslet, jakým stylem budu učit... Jestli budu mit v těch hodinách prezentaci nebo budu mit výklad. Jestli ten výklad budu mit predtím, než si budou psát..."(Karolína)

Začínající učitelé, kteří již měli za sebou dva roky a více strávené ve školní praxi, se nezmiňovali ani tak o problémech, jako spíš o vnímaných nedostatcích, které ve své výuce či prípravách díky průběžné reflexi pozorovali. Uváděli, že se snaží svou výuku zlepšovat a přizpůsobovat schopnostem žáků, které měli možnost v předchozí fázi poznat: „Už mám základ, ale stejně furt vychytávám, co by šlo lipp..., protože ty děti nějakým zpiosobem na to reagujou a řeknu si: ,Aha, tak takble to príště neudèlám, udělám to... jinak" "(Julie)

Výše vnímané precizování vlastní výuky pak mělo vliv na hodnocení oborově didaktické př́pravy, konkrétně pak na hodnocení mikrovyučování, definovaného jako krátké simulace vyučovacích hodin, kdy si studenti učitelství zkouší nacvičovat, jak vyučovat, a to před svými spolužáky, v „bezpečných“ podmínkách v rámci vysokoškolských předmětů. Začínající učitelé, kteří se zmiňovali o nedostatečně rozvinutých dovednostech $\mathrm{v}$ prvním až třetím roce a zároveň neměli př́iliš možností si na vysoké škole tyto dovednosti osvojit v rámci mikrovyučování, považovali neprocvičení vlastního vedení výuky za př́činu své nepřipravenosti: „Jak prostě to správně podávat tèm dètem... tomu se nevènovalo podle mýho... dostatečnej časovej uisek a dostatečnýho cvičeni." (Jakub) 
Tito učitelé proto navrhovali zavedení mikrovyučování a jeho reflexi: „Zadávat... úkoly.... , Predstavit si, že my všichni jsme napríklad v sedmé trídě... žáci a vysvětli nám tady ten problém... A my si to zkusime představit. Samozřejmè ta zpětná vazba nemusi být úplné objektivní..., ale je nás tu dvacet, tak my ti zkusime ríct, co si treba myslime, že bys mohl ríct jinak' "(Renata)

Pokud respondenti mikrovyučování absolvovali, a přesto jim mnohé dovednosti v prvních třech letech chyběly, nahlíželi na mikrovyučování jako na neautentické a neschopné připravit začínající učitele na tyto dovednosti. Doptáváním se po př́činách této kritiky jsme rozkryly, že neautentičnost nevyvolává samotné mikrovyučování, ale vyučující didaktického předmětu bez zkušenosti $s$ výukou na ZŠ či SŠ́ „... to ve vetšinou učí.. lidi, který v ži $i$ votě neučili, takže i když jsou fajn, tak prostě není... tam... ta zkušenost." (Karolína); „Opravdu by to chtélo, aby tu didaktiku... učili ty lidi praxe..., který... ř́kaji ty věci, jak to opravdu funguje, a ne... néco načtenýho z knižek, protože tam ta realita... neni." (Monika)

Z výše uvedeného je patrné, že respondenti v rámci hodnocení didaktické prípravy oceňují, stejně jako tomu bylo v reakcích na pedagogicko-psychologický blok, nácviky reálných situací a formulují požadavek na takové vysokoškolské učitele, kteří jim zprostředkují reálnou zkušenost $s$ vedením vyučovací hodiny ve vztahu $\mathrm{k}$ co nejreálnějším školním podmínkám.

Do určité míry se jedná o inverzní požadavek vůči hodnocení odborné složky pregraduální přípravy (viz dále), kdy to, že vysokoškolský učitel nemá prrímou spojitost se školní praxí, není vnímáno jako handicap - na rozdíl od požadavku na vysokoškolské učitele, kteří zajištují pregraduální prŕípravu $\mathrm{v}$ pedagogicko-psychologických a oborově didaktických předmětech.
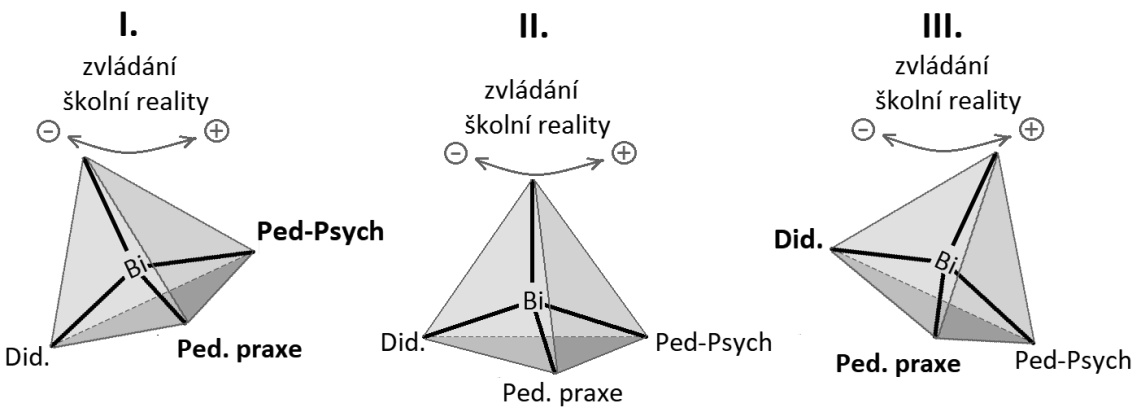

Obr. 3. Vliv vnímání vlastní úspěšnosti ve zvládání školní reality na hodnocení jednotlivých složek pregraduální př́ípravy

Legenda: Did. - oborově didaktická prríprava (didaktika Bi/Př), Ped. praxe - pedagogické praxe, Ped-Psych pedagogicko-psychologická prííprava 


\subsubsection{Modelování analyzované skutečnosti}

Analýzou výzkumných dat jsme ve vztahu $\mathrm{k}$ interpretovanému $\mathrm{v}$ předešlém textu a v souladu $s$ obr. 1 vysledované tř́i okruhy náhledů na hodnocení pregraduální př́ípravy vizualizovaly (viz obr. 2). Tím se vracíme k centrálnímu jevu a zviditelňujeme jej v jeho dynamické podobě. $Z$ vizualizace pak je patrný i dosud nezmíněný zbývající náhled hodnocení pregraduální př́pravy.

Z obrázku 3, kde připodobňujeme složky pregraduální př́ípravy a zvládání školní reality $\mathrm{k}$ tetraedru, je patrné, že jako nejstabilnější složka pregraduální přípravy je hodnocená oborová složka (blíže k ní viz níže). Na základě analýzy výpovědí respondentů je nezbytné vzít v potaz i pedagogické praxe, které jsou povinnou součástí pregraduální př́ípravy a dokreslují nahlížení respondentů na pregraduální př́pravu ve vztahu $\mathrm{k}$ pedagogicko-psychologickému a oborově didaktickému bloku.

To, jak se $\mathrm{v}$ počátcích začínající učitelé sami více či méně úspěšně vypořádávali s nekázní žáků ve školní realitě - hlavním faktorem úspěšného sžívání se $s$ realitou - ovlivňovalo nazírání na pregraduální př́pravu a její reflexi zejména $\mathrm{v}$ rovině pedagogicko-psychologické, př́p. oborově didaktické složky. Ti začínající učitelé, kteří nemuseli tolik řešit kázeňské problémy či se nad ně dokázali povznést, oscilovali mezi těmito složkami s cílem „hlavně, at to jde“, kdy se respondenti tzv. hledají a jejich snaha sžít se se školní realitou je zaměřena na mnoho aspektů (nedostatek času na př́pravu, neschopnost naplňovat tematický plán, náročná administrativa, nefungující technika aj.), které je vyvádějí z rovnováhy, byt ne tak dramaticky, jako ty začínající učitelé spadající do sféry okruhu I na obrázku 3.

U respondentů spadajících do první sféry jsme navíc zaznamenaly následující úvahy: „No a pak párkrát... príjdu domů:..., Kašlu na to, dělat to nebudu jo. A nebavi mé to, nejsem pro to prostè stvorená...'Takže... záríi, ř́jen, probihalo jenom to, že jsem prišla domù a brečela jsem nebo jsem nadávala..." (Pavla); „První týden... jsem jako každej večer brečela a chtěla jsem odsud odejit, a protože jsem trávila opravdu prípravou každý hodiny... čtyřri až pět hodin..., a pak príideš do tý trídy a oni ti řeknou: ,To už jsme dělali.' Dobrý, to zkousneš jednou. Když máš... plnej úvazek a tohle se ti stane šestkrát dennè, tak tě to jako pomèrně dost vyčerpá, protože nemás tady toho člověka, kterej tady byl pred tebou a nemás se čeho chytit. Takže to jako bylo náročný." (Klára)

$\mathrm{Z}$ pohledu této studie jsou právě začínající učitelé z první sféry, částečně i ze druhé, nejvíce ohroženi odchodem ze školní praxe.

\subsection{Hodnocení pregraduální př́ípravy ve vztahu k odborně- -oborové složce}

K dokreslení pregraduální prrípravy chybí zohlednit samotný studovaný vzdělávací obor a to, jak začínající učitelé reflektují tuto složku v pregraduální prrípra- 
vě. Hodnocení odborně-oborové složky se neodvíjelo od jejich celkového vnímání toho, zda novou školní situaci zvládají, či nikoli. Žádný z oslovených začínajících učitelů se nezmiňoval o tom, že by byl nedostatečně připraven po odborné biologické stránce. Učitelé uváděli, že ačkoli velké množství poznatků získaných během studia na vysoké škole nebylo na ZŠ a SS často př́ímo využitelné, podporovaly tyto znalosti jejich sebedi̊věru ve vlastní odbornost. Proto byla tato složka pregraduální př́pravy hodnocena nejlépe: „... teorie bylo hodnè, ale... občas je to potřeba... bejt na nějaký vyšsi úrovni, aby to člověk dokázal... perfektnè vysvétlit. “(Jakub); „... hodně prínosné... byly... určitě odborné prèdméty prírodopis, chemie..., pak jako riozné terénni práce, co jsme mèli na prírodopisu... stran určováni prírodnin a poznáváni té prírody, protože na to se ty děti ptaji vždycky. To je vždycky zajimá: ,Co to je? " (Renata); „Myslim si, že... po tý védomostni stránce, tak jako pripravený perfektné jsme, ale z hlediska toho učitelováni..." (Kristýna)

Výzkumným šetřením nebyly mezi začínajícími učiteli z pedagogických či prýirodovědeckých fakult ve vztahu k odborné biologické složce ani $\mathrm{v}$ tomto př́padě shledány rozdíly.

\section{DisKUSE A PROJEKCE POSÍlENí PREGRADUÁLNÍ PŘíPRAVY VE VZTAHU KE ŠKOLNÍ PRAXI}

$\mathrm{Z}$ analýzy rozhovorů vyplynulo, že jak naši respondenti, tak respondenti jiných českých (Kalhoust \& Horák, 1996;
Šimoník, 2004; Vítečková \& Gadušová, 2015) i zahraničních (Hesson, 2016; Salazar Noguera \& McCluskey, 2017) výzkumů kladně hodnotili výuku oborové odbornosti a zároveň nejčastěji byli ve svých raných počátcích šokováni žákovskou nekázní (viz také Buchanan, 2002; Chesley \& Jordan, 2012; Salazar Noguera \& McCluskey, 2017; Sandoval-Lucero et al., 2011). Příčinou toho byla nepřiměřená očekávání pocházející převážně $\mathrm{z}$ teoretické výuky pedagogicko-psychologické složky př́ípravy (viz také Buchanan, 2002; Salazar Noguera \& McCluskey, 2017; Swabey et al., 2010). Vzhledem k tomu, že $\mathrm{k}$ účinné výuce je $\mathrm{z}$ počátku nutné zvládnout řízení trrídy, zastínila tato výzva úkoly jiné, související např. s výukou žáků. Tento jev shodně vysvětluje Šimoník (1995) či Dropkin a Taylor (1963), podle kterých je pro uvědomění si problémů s výukou nutný jistý nadhled, který učitelé získají až po určité době. $V$ naší studii odpovídala tato „doba“ období, kdy se začínající pedagogové učili tzv. za běhu vypořádat $s$ nekázní žáků i s dalšími aspekty školní reality, jako je např. administrativa, nedostatek času na prrípravy a problémy $s$ didaktickou technikou. Po vyřešení této první nesnáze se začínající učitelé začali více věnovat evaluaci žákovských činností a samotné vyučovací hodině, a v souvislosti $s$ tím začali také spatřovat určité nedostatky $\mathrm{v}$ oborově-didaktické složce př́ípravy. Vzhledem k tomu, že se do této fáze dostali jen někteří začínající učitelé, zatímco první dimenzí si prošli všichni, týkala se většina kritiky pedagogicko-psychologické složky. 
Výše popsanou teorii lze znázornit také graficky prostřednictvím modelu tetraedru (viz obr. 3). Pro začínající učitele, kteří nastoupí do školní praxe, je typické, že se setkávají s nekázní žáků, kterou nedokáží optimálně řešit. To vede $\mathrm{k}$ pocitu selhání a k negativnímu hodnocení ve vztahu $\mathrm{k}$ pedagogicko-psychologické složce (obr. 3-I), který akcentuje rohy tetraedru reprezentující pedagogicko-psychologickou složku př́ípravy do výšky, což naznačuje zvýšenou pozornost a v našem prrípadě i kritičnost začínajících učitelů $\mathrm{k}$ této složce př́ípravy. Postupně, jak se začínající učitel zdokonaluje ve zvládání žákovské nekázně, posouvá se jeho mínění týkající se zvládání školní reality ke kladnějším hodnotám. $\mathrm{V}$ důsledku toho se zvedá opačná strana tetraedru reprezentující didaktickou složku přípravy a pozornost se v tuto chvíli upíná $\mathrm{k}$ ní.

Můžeme tedy říci, že to, zda se začínající učitelé zabývají hodnocením pouze pedagogicko-psychologické složky prípravy nebo také oborově-didaktické složky, nezáleží ani tak na konkrétní vysoké škole, ale zejména na fázi profesního vývoje začínajících učitelů (viz také Choy et al., 2013). Zároveň nebyly shledány souvislosti mezi hodnocením a délkou praxe. $\mathrm{Z}$ toho vyplývá, že fáze profesního vývoje, ve které se začínající učitelé nacházejí, musí být kromě délky praxe ovlivněna i dalšími faktory, jako jsou podmínky školního prostředí či osobní charakteristiky, napřr. předchozí zkušenosti či profesní kompetence (viz též Day, 1999; Fessler et al., 1984; Richardson \& Placier, 2001).
Dáme-li do vztahu hodnocení pregraduální přípravy u dvou začínajících učitelů, kteří absolvovali stejnou vysokou školu, ale učí na jiných školách, přičemž nerozhoduje, zda na základní nebo střední, je nasnadě, že se bude lišit. Př́činy odlišného hodnocení lze vedle individuálních rozdílů mezi začínajícími učiteli, jako je např. osobnost, předchozí zkušenosti či délka praxe, hledat i v podmínkách, které na začínající učitele během jejich učební praxe na dané škole působily či působí. Například podle Hessonové (2016) zvyšuje nedostatečné uvádění začínajících učitelů do školní praxe jejich pocit nepřipravenosti, což koreluje $s$ naším zjištěním, že kritika pedagogicko-psychologické prípravy byla často umocněna prítomností pouze formální podpory $\mathrm{v}$ podobě uvádějícího učitele (o této funkci čtyři $\mathrm{z}$ našich respondentů vůbec neslyšeli), či její úplnou absencí $\mathrm{v}$ prrípadě, že začínající učitel byl jediným učitelem biologie na škole. Absence fungujícího a zároveň dostupného uvádějícího učitele, který je sám iniciativní a cíleně podrží začínajícího učitele při řešení kázeňských obtíží, se pak logicky odrazila v kritice pedagogicko-psychologické složky prŕpravy - jediném potenciálním zdroji znalostí, který se však ukázal jako nepostačující. Vzhledem k tomu, že v odborné a oborově-didaktické složce nalézali začínající učitelé větší oporu oproti složce pedagogicko-psychologické, je pravděpodobné, že tento faktor sehrával roli v méně kritickém hodnocení odborné a (oborově) didaktické složky př́ípravy.

$\mathrm{V}$ současném zahraničním i českém diskurzu je ceněna výuka zaměrená 
na žáky (Chesley \& Jordan, 2012; Rajsiglová \& Přibylová, 2020; Salazar Noguera \& McCluskey, 2017; Sandoval-Lucero et al., 2011; Švec, 2006), kterou požadují také kurikulární dokumenty rámcových vzdělávacích programů. $\mathrm{Na}$ to upozorňují i respondenti této studie, kteří volají po jiných formách výuky, jako je např. situační učení, při kterém jsou sami aktéry, a to zejména $\mathrm{v}$ pedagogicko-psychologických a oborově-didaktických předmětech.

Návrh začínajících učitelů, aby se úpravy pregraduální prrípravy týkaly zejména forem výuky, kdy je žádoucí, aby výuka pro budoucí pedagogy probíhala pomocí širokého spektra metod, v nichž jsou sami studenti v centru dění, je ve shodě $s$ mnoha autory (např. Chesley $\&$ Jordan, 2012; Salazar Noguera \& McCluckey, 2017; Sandoval-Lucero et al., 2011). Šimoník (1995, s. 71) k tomu poznamenává, že příprava budoucích učitelů by měla být pouze jednou z počátečních fází celoživotního vzdělávání, a proto by měla být více zaměřená na to, co bude začínající učitel v prvních letech skutečně potřebovat. Jak náš i jeho výzkum naznačují, právě neschopnost zvládnout kázeň žáků je první překážkou $\mathrm{v}$ následné úspěšné výuce žáků. Pokud tedy nebude v pregraduální př́ípravě tato základní dovednost posilována, nebude možné kvalitně zúročit dovednosti získané $\mathrm{v}$ jiných tématech pregraduální př́ípravy.

V následujícím textu přiblížíme analyzované skutečnosti obsažené $\mathrm{v}$ předchozí kapitole ve vztahu k současným paradigmatům nahlížení na pregraduální príípravu budoucích učitelů.
Přestože všichni začínající učitelé shodně reflektují rezervy zejména $\mathrm{v}$ pedagogicko-psychologické přípravě, rozpoznáváme, že podstata nesouhlasu je patrná naprííc všemi složkami pregraduální prŕípravy.

To, že začínající učitelé navrhují navýšení dotací pedagogických praxí, vysokoškolskou výuku např̀. prostřednictvím zážitkových metod, diskusí nad reálnými školními situacemi či propojování teorie a praxe prostřednictvím př́iběhů a návodů, jak se vypořádat zejména s nekázní žáků, je deskripce návrhů na update pregraduální př́ípravy vyvoditelný i z literatury (viz úvodní části textu). Nicméně z výpovědí a analýzy výzkumu dedukujeme hlubší konfrontaci pregraduální výuky začínajících učitelů ve vztahu $\mathrm{k}$ jejich hladkému počátku v reálné praxi. Dané lze demonstrovat následujícími výroky:

"Viobec jsme nebyli zvykli bejt s tèma dètma, reagovat na nè, jak pracovat s tichem, jak pracovat s lidma, který vyrušujou. $\mathrm{Na}$ škole tè učejí, priprav si látku, vymysli metody, ale to, že je ta trída... živej kolektiv, to ti nikdo jako neŕekne."(Klára)

„Kdybychom méli teorii... a dalši hodinu šli do školy a podivali se, ... jestli se tam tohleto dèje a jak to ten učitel vyřešil, ... divat se, jak ty dèti pracujou. Jak... s nima jednaji ti učitelé. Jakoukoli věc, kterou chcete dělat dobre, musite zažit." (Pavla)

"Ty teoretici a psychologové, pedagogové by mèli navštèvovat ty školy a pozorovat ty dèti... At'tam strávi tréba celej ten mèsic... Měl mit nějakej dar slova, kterým to dokáže ríct... tèm... studentuim, který se pripravujou na tohleto zamèstnání. Co dèlat přesnè, jak to ditě $k$ něčemu primèt. "(Jakub) 
Sledovaní začínající učitelé pravděpodobně nevolají po posílení v pedagogicko-psychologické složce na jedné straně či adekvátněji ke školní praxi vedených oborově-didaktických předmětech na straně druhé. Cílí na propojování a integraci všech složek pregraduální přípravy, které by vyústilo např̀. $v$ takové předměty, kdy se propojí pedagogicko-psychologická, oborově didaktická i odborná př́íprava.

Ve vztahu k tomu dedukujeme, že pokud budou budoucí učitelé řešit $\mathrm{v}$ rámci vysokoškolské výuky samostatně nekázeň a jak se $s$ ní vypořádat a následně až $\mathrm{v}$ dalším roce studia (nebo i v rámci semestru, ale za jiných podmínek a $s$ jiným kontextem $\mathrm{v}$ rámci jiného předmětu) to, jak si mají připravit vyučovací hodinu (zejména při ní dochází k nekázni žáků, kterou musí začínající učitelé obratem vyřešit, a navíc musí zvládnout tuto vyučovací hodinu „dovést" $\mathrm{v}$ rámci možností zdárně do jejího konce), nebude docházet $\mathrm{k}$ propojení naučeného. Začínající učitelé volají po tom, aby se v pregraduální přípravě objevovaly takové předměty, jejichž cílem bude $\mathrm{v}$ jednom okamžiku, na jednom místě a s komplexním prístupem $\mathrm{k}$ řešené situaci - optimálně co nejvíce podobné reálné školní - propojení a aplikování poznatků pedagogicko-psychologické, oborově-didaktické i odborné složky pregraduální př́ípravy. Toto je legitimním požadavkem začínajících učitelů a může podpořit hladký start ve školní praxi.

Domníváme se, že na problematiku pregraduální prrípravy je potřebné nahlížet tímto prizmatem, a za daných okolností provádíme revizi tetraedrické vizua- lizace vztahu složek pregraduální přípravy (obr. 4). Pro vizualizaci volíme tvar tetraedru záměrně, jako symbol, nebot' z jeho středu je stejně daleko ke všem vrcholům a zároveň za vrchol lze považovat kterýkoli roh podle toho, jak zrovna tetraedrem otočíme a jak ho postavíme na stabilní trríbodovou základnu. Navíc nahrazujeme biologii nadřazeným termínem obor, aby bylo zřejmé, že dané lze definovat pro jakýkoli studovaný vzdělávací obor budoucích učitelů.

Pokud studenti, budoucí učitelé, dostatečně procvičí jak reagovat na školní realitu (nekázeň žáků, př́íprava na vyučovací hodinu vedle nezbytné administrativní zátěže při chodu školy, tř́́dní schůzky $s$ různě reagujícími rodiči), pak si mohou v rámci tetraedrické vizualizace sáhnout do té oblasti pregraduální prrípravy, kterou aktuálně řeší, a zúročit její vyučované obsahy.

Střední a základní školy se musely vypořádat $s$ "nařízeními“ vycházejícími $\mathrm{z}$ rámcových vzdělávacích programů (Balada et al., 2007, 2017), kdy je po nich požadováno výuku směrovat ke klíčovým kompetencím, $\mathrm{k}$ interdisciplinaritě a mezioborovým přesahům a používat takový způsob vedení výuky, který vedle metod již zaběhlých a desetiletí používaných bude obohacen o další, dříve méně běžné aktivity a techniky využívající „inovativní" metody a formy. Totéž požadují začínající učitelé naší studie ve vztahu $\mathrm{k}$ pregraduální přípravě budoucích učitelů. Přestože existují standardy popisující závaznou strukturu učitelských studijních programů (Metodické pokyny MŠMT. 


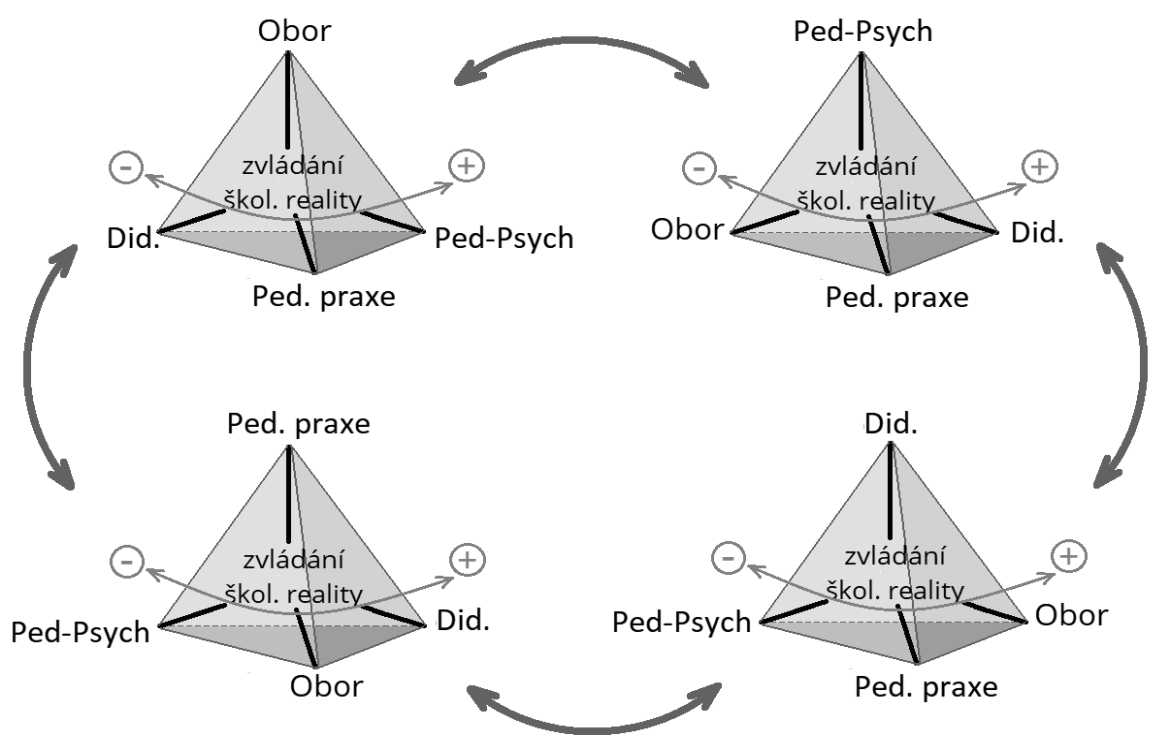

Obr. 4. Optimalizace pregraduálního vzdělávání ve vztahu ke zvládání školní reality

2017), chybí explicitní požadavek na takový způsob vedení vysokoškolské výuky pro budoucí učitele, který by viditelně posiloval to, co je požadováno po učitelích základních a středních škol a co by vysokoškolští pedagogové, jako nositelé vzoru a ideálu, předávali studentům učitelství, budoucím učitelům na našich základních a středních školách.

Je na diskusi v akademické obci, jak dané zohlednit a propojit s kariérními kritérii hodnocení vysokoškolských pedagogů, kteř́ se na prrípravě budoucích učitelů aktivně podílejí. Jsme toho názoru, že adekvátní obsahová náplň pregraduální př́ípravy by měla optimalizovat akademický koncept vzdělávání budoucích učitelů, stavící do popředí tradiční vysokoškolské pojetí vzdělávání $\mathrm{v}$ podobě důrazu na odborné znalosti, a zároveň zohledňovat kompetenční koncept, „založený na získávání specifických profesních kompetencí a ... vázaný na profesi, obsahovou a osobnostní složku profesního standardu učitele" (Urbánek, 2016, s. 48-49), a podporovat $\mathrm{v}$ budoucích učitelích proces stávání se učitelem (Spilková, 2004), kdy na základě vlastních zkušeností a činností i hledání sebe sama v roli učitele, díky pomoci vysokoškolských pedagogů, fakultních učitelů a spolužáků si budoucí učitelé „osvojuji “ učitelskou profesi.

Domníváme se, že oba přístupy, akademický i kompetenční (Urbánek, 2016), 
nemusí stát proti sobě na opačných stranách, ale $\mathrm{v}$ průběhu studijních let se mohou doplňovat a spirálovitě prolínat, nebot teoretický základ bude podpořen návrhy reálných řešení situací, které se mohou v různé míre ve školní praxi objevovat. Souzníme s myšlenkou Kasíkové (2016, s. 127), aby se studenti učitelství $\mathrm{v}$ průběhu studia setkávali $s$ takovými modely výuky, které je budou „pozitivně ovlivňovat v jejich budoucí praxi“".

Diskuse $\mathrm{k}$ pregraduální prípravě studentů učitelství kontinuálně probíhá, je tedy žádoucí, aby vysoké školy prezentovaly budoucím učitelům školní realitu co nejvěrněji, tedy $\mathrm{v}$ její nezjednodušené podobě, a upevňovaly ve studentech učitelství jistotu, že dokáží co nejadekvátněji reagovat na mnohé školní situace, přičemž řešení těchto situací může být několik, ne právě jen jedno možné. Tím posílíme jejich autonomii v nazírání, vyhodnocování a výběru optimálního řešení školních situací.

\section{ZÁVĚR}

V této studii jsme se zabývaly otázkou, jak začínající učitelé vnímají vliv jednotlivých složek pregraduální prrípravy na průběh jejich prvních let praxe. Přestože je problematika začínajících učitelů a jejich vzdělávání mezi českou i zahraniční pedagogickou veřejností řešena poměrně často, domníváme se, že tím, že naše zjišstění vycházejí z názorů různě zkušených začínajících učitelů $\mathrm{z}$ praxe, přispíváme k rozkrývání jejich potřeb v kontextu (ne) úspěšných počátků ve školní praxi. Ukázaly jsme, že dané lze znázornit graficky prostřednictvím modelu tetraedru (viz obr. 3), přičemž jej následně optimalizujeme a vizualizujeme nezbytné interdisciplinární i naddisciplinární propojování naučeného obsahu $\mathrm{v}$ rámci jednotlivých složek pregraduálního vzdělávání (viz obr. 4). $Z$ výpovědí respondentů explicitně nevyznívala zřetelná podpora ze strany dané školy. To jsme cíleně do našeho výzkumu, z důvodu již tak obsáhlého pokrytí tématu, nezahrnovaly, nicméně jsme si vědomy toho, že to lze považovat za limitu výzkumu. To podněcuje cestu $\mathrm{k}$ dalším výzkumům, nebot' je potřebné prozkoumat, nakolik se jedná skutečně o respondenty deklarovanou formální podporu, př́íp. rozkrýt, jak školy zajištují podporu nováčků ve svém kolektivu, když tito ji explicitně nevnímají. To vnímáme jako podnět pro další zkoumání obtíží začínajících učitelů, které by dokreslilo problematiku hladkého startu učitelů ve školní praxi.

Poděkování: Rády bychom poděkovaly všem začínajícím učitelům, kteří nám věnovali svůj čas a s důvěrou odpovídali na naše dotazy. Dále děkujeme UNCE/ HUM/024 - "Centrum didaktického výzkumu v přírodních vědách, matematice a jejich mezioborových souvislostech" za poskytnutou podporu. Autorky dále děkuji recenzentce za podnětné kritické připomínky, které vedly $\mathrm{k}$ přepracování původně zaslaného textu. 


\section{LITERATURA}

Balada, J. et al. (2007). Rámcový vzdělávaci program pro gymnázia: RVP G. Praha: Výzkumný ústav pedagogický.

Balada, J. et al. (2017). Rámcový vzdělávaci program pro základni vzděláváni. Praha: Výzkumný ústav pedagogický.

Berliner, D. C. (1989). Implications of studies of expertise in pedaggoy for teacher education and evaluation. In New directions for teacher assessment: Proceedings of the 1988 ETS Invitational Conference (s. 39-68). Princeton, New Jersey: Educational Testing Service.

Buchanan, J. (2002). What they should have told me: Six beginning teachers' reflections on their pre service education in the light of their early career experiences. Curriculum Perspectives, 26(1), 47-56.

Darling-Hammond, L. (2003). Keeping good teachers: Why it matters, what leaders can do. Educational Leadership, 60(8), 6-13.

Day, C. (1999). Developing teachers: The challenges of lifelong learning. London: Falmer Press.

Dropkin, S., \& Taylor, M. (1963). Perceived problems of beginning teachers and related factors. Journal of Teacher Education, 14(4), 384-390.

Burke, P. J., Christensen, J. C., \& Fessler, R. (1984). Teacher career stages: Implications for staff development. Bloomington, Indiana: Phi Delta Kappa Educational Foundation.

Friedman, I. A. (2000). Burnout in teachers: Shattered dreams of impeccable professional performance. Journal of Clinical Psychology, 56(5), 595-606.

Gillernová, I. (2003). Sociální dovednosti jako součást profesní kompetence učitele. Pedagogická orientace, 13(2), 83-94.

Glaser, B. G., \& Strauss, A. L. (2006). The discovery of grounded theory: Strategies for qualitative research. New Brunswick: Aldine Transaction. (Poprvé publikováno v roce 1967).

Hendl, J. (2005). Kvalitativni výzkum. Základni metody a aplikace. Praha: Portál.

Hesson, N. (2016). How do selected novice middle school teachers from various certification pathways perceive the effectiveness of their teacher preparation? Middle Grades Review, 2(1), 1-14.

Chesley, G. M., \& Jordan, J. (2012). What's missing from teacher prep. Educational Leadership, $69(8), 41-45$.

Choy, D., Wong, A. F. L., Lim, K. M., \& Chong, S. (2013). Beginning teachers' perceptions of their pedagogical knowledge and skills in teaching: A three year study. Australian Journal of Teacher Education, 38(5), 68-79.

Jensen, B., Sandoval-Hernández, A., Knoll, S., \& Gonzalez, E. J. (2012). The experience of new teachers: Results from Talis 2008. OECD Publishing.

Johnson, B., Down, B., Le Cornu, R. et al. (2014). Promoting early career teacher resilience: A framework for understanding and acting. Teachers and Teaching: Theory and Practice, 20(5), 530-546.

Kalhoust, Z., \& Horák, F. (1996). K aktuálním problémům začínajících učitelů. Pedagogika, 46(3), $245-255$.

Kasíková, H. (2016). Teorie učitelského vzdělávání v kontextu vysokoškolské pedagogiky. In M. Strouhal (Ed.), Učit se být učitelem: Kvybraným problémưm učitelského vzdělávání. Praha: Karolinum. 
Kugel, P. (1993). How professors develop as teachers. Studies in Higher Education, 18(3), 315-328. Miovský, M. (2006). Kvalitativni prístup a metody v psychologickém výzkumu. Praha: Grada.

Píšová, M., \& Hanušová, S. (2016). Začínající učitelé a drop-out. Pedagogika, 66(4), 386-407.

Píšová, M., Najvar, P., Janík, T. et al. (2011). Teorie a výzkum expertnosti v učitelské profesi. Brno: Masarykova univerzita.

Metodické pokyny MŠMT. 2017. Rámcové požadavky na studijni programy, jejichž absolvováním se ziskává odborná kvalifikace k výkonu regulovaných povoláni pedagogických pracovniků, ze dne 5. 10. 2017 čj. MSMT 21271/2017-5. Dostupné z www.msmt.cz

Rajsiglová, J. (2019). Contemplation of activating teaching methods in science education in undergraduate training of pedagogical students. In M. Rusek \& K. Vojirir (Eds.), Project-based education in science education XV. (s. 90-97). Praha: Pedagogická fakulta Univerzity Karlovy.

Rajsiglová, J., \& Přibylová, K. (2020). Micro-teaching as a strategy of learning to teach from the perspective of novice teachers. In M. Rusek, M. Tóthová \& K. Vojiŕ (Eds.), Project-based education and other activating strategies in science education XVII (s. 155-162). Praha: Pedagogická fakulta Univerzity Karlovy.

Richardson, V., \& Placier, P. (2001). Teacher change. In V. Richardson (Ed.), Handbook of research on teaching (s. 905-947). 4. vyd. Washington, D. C.: American Educational Research Association.

Salazar Noguera, J., \& McCluskey, K. (2017). A case study of early career secondary teachers' perceptions of their preparedness for teaching: lessons from Australia and Spain. Teacher Development, 21(1), 101-117.

Sandoval-Lucero, E., Shanklin, N. L., Sobel, D. M., Townsend, S. S., Davis, A., \& Kalisher, S. (2011). Voices of beginning teachers: Do paths to preparation make a difference? Education, 132(2), 336-350.

Shulman, L. S. (1987). Knowledge and teaching: Foundations of the new reform. Harvard Educational Review, 57(1), 1-23.

Spilková, V. (2004). Současné promèny vzdělávání učitelů. Brno: Paido.

Spilková, V., \& Vašutová, J. (2008). Učitelská profese v ménicich se požadavcich na vzdèlání. Praha: Pedagogická fakulta Univerzity Karlovy.

Strauss, A., \& Corbinová, J. (1999). Základy kvalitativního výzkumu: postupy a techniky metody zakotvené teorie. Brno: Společnost Podané ruce.

Swabey, K., Castleton, G., \& Penney, D. (2010). Meeting the Standards? Exploring Preparedness for Teaching. Australian Journal of Teacher Education, 35(8), 29-46.

Šimoník, O. (1995). Začinajici učitel: Některé pedagogické problémy začinajicićch učitelü. Brno: Masarykova univerzita.

Šimoník, O. (2004). Pedagogická praxe v kontextu pregraduální př́ípravy. In J. Havel \& T. Janík (Eds.), Pedagogická praxe v pregraduální prípravè učitelù (s. 13-16). Brno: Pedagogická fakulta Masarykovy univerzity.

Švec, V. (2006). Od znalostí k pedagogické kondici: nový vhled do pedagogické prípravy studentů učitelství? Pedagogika, 56(1), 91-102. 
Urbánek, P. (2016). Akademický či kompetenční koncept vzdělávání učitelů. Nutná bipolarita? In M. Strouhal (Ed.), Učit se být učitelem: Kvybraným problémům učitelského vzdèlávání(s. 44-69). Praha: Karolinum.

Vašutová, J. et al. (2008). Vzděláváme budouci učitele. Nové př́stupy k pedagogickopsychologické prípravě studentů učitelství. Praha: Portál.

Vítečková, M., \& Gadušová, Z. (2015). Vysokoškolské studium učitelství z pohledu začínajícího učitele a identifikace jeho problematických oblastí. Edukácia, 1(1), 266-275.

RNDr. Ina Rajsiglová, Ph.D.

Katedra učitelství a didaktiky biologie, Prírodovédecká fakulta Univerzity Karlovy;

e-mail: ina.rajsiglova@natur.cuni.cz

Mgr. Katerina Pribylová

VOŠ, SOŠP a Gymnázium, Evropská 33, Praha 6

\section{RAJSIGLOVÁ, I., PŘIBYLOVÁ, K. The Influence of Undergraduate Education on Professional Beginnings in School Practice from the Perspective of Novice Teachers}

The aim of the paper is to present how the novice teachers who were followed perceive the impact of undergraduate training on their first years of practice and what can be seen in this way to improve the quality of training of future teachers.

Methods: The research sample consists of thirteen novice biology teachers with experience ranging from one to five years. The data was obtained through in-depth semi-structured interviews and was analysed by grounded theory.

The results show that the component of vocational biological training was the one which was evaluated most highly, with the pedagogical-psychological component before the (subject-related) didactic component causing the greatest reservations. As part of the pedagogical-psychological and didactic component of undergraduate training, the teachers suggested increasing the amount of classroom observation, the application of experiential teaching, or the mediation of teaching by university educators or experts with real work experience in school practice. The assessment of their undergraduate training was influenced by the shock of the reality of school, caused by the unrealistic expectations of novice teachers.

Conclusions: We consider the contribution of this study to be that despite a certain individuality of views, some trends have been observed that could be taken into account in the preparation of future teacher education programmes, and that we have managed to uncover the key links between the different components of undergraduate training, which was visualized by means of an abstract scheme in the form of a tetrahedron.

Keywords: novice teacher, problems of novice teachers, evaluation of undergraduate training, possibilities of adjusting undergraduate training, school reality. 
Rajsiglová, I., Pribylová, K.

\begin{tabular}{|c|c|c|c|c|c|c|c|}
\hline \multicolumn{5}{|c|}{ VÝUKA ZAMĚŘENÁ NA UČENÍ ŽÁKA } & \multicolumn{3}{|c|}{ HLAVNĚ } \\
\hline \multicolumn{2}{|l|}{ 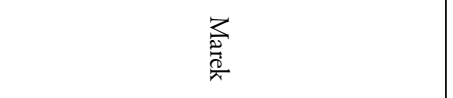 } & \multicolumn{2}{|l|}{ 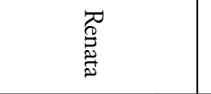 } & 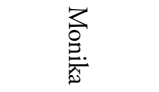 & $\begin{array}{l}\overrightarrow{\vec{E}} \\
\vec{E}\end{array}$ & \multicolumn{2}{|c|}{ 㞼蛋 } \\
\hline \multicolumn{2}{|l|}{ 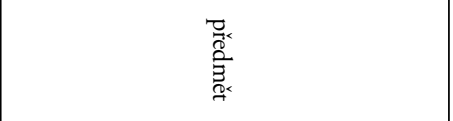 } & \multicolumn{2}{|l|}{ 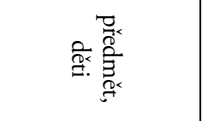 } & 菊 & 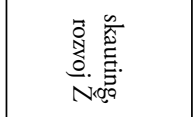 & \multicolumn{2}{|c|}{ 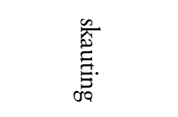 } \\
\hline \multicolumn{2}{|l|}{ 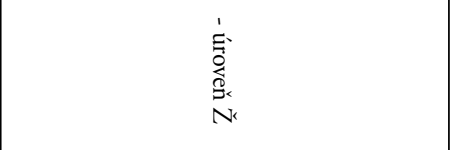 } & \multicolumn{2}{|l|}{ 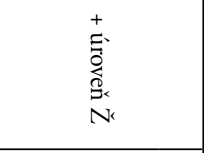 } & 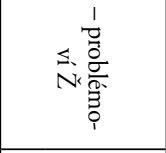 & 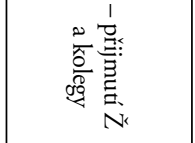 & \multicolumn{2}{|c|}{ 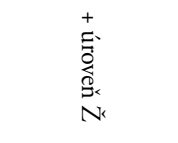 } \\
\hline \multicolumn{2}{|l|}{ 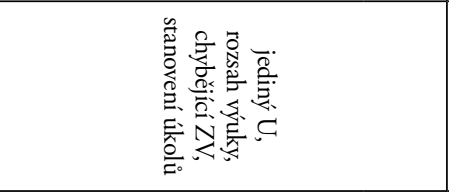 } & \multicolumn{2}{|l|}{ 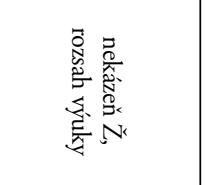 } & 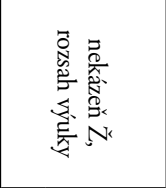 & 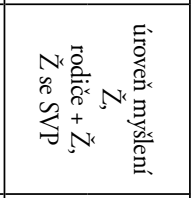 & \multicolumn{2}{|c|}{ 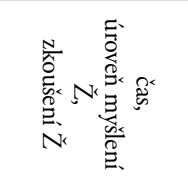 } \\
\hline \multicolumn{2}{|l|}{ 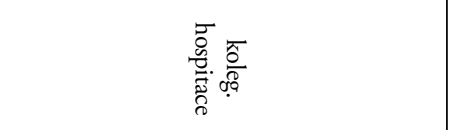 } & 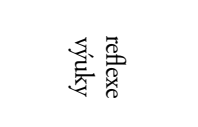 & \multicolumn{2}{|c|}{ 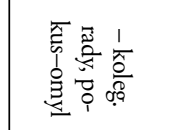 } & 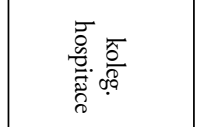 & \multicolumn{2}{|c|}{ 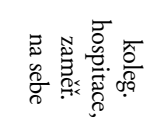 } \\
\hline 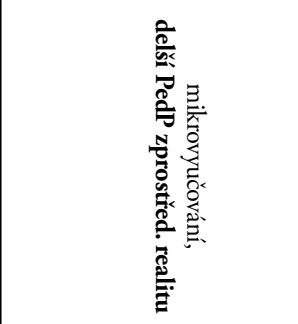 & 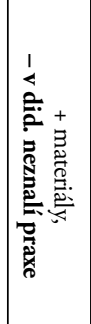 & 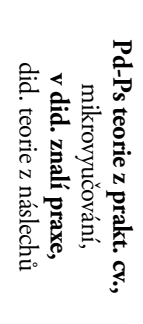 & 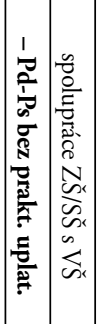 & 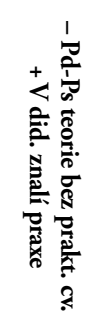 & 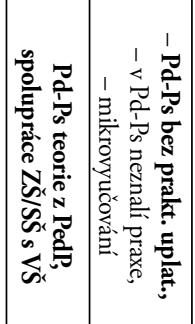 & 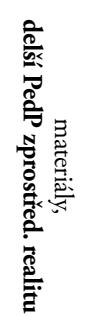 & 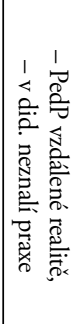 \\
\hline \multicolumn{5}{|c|}{ 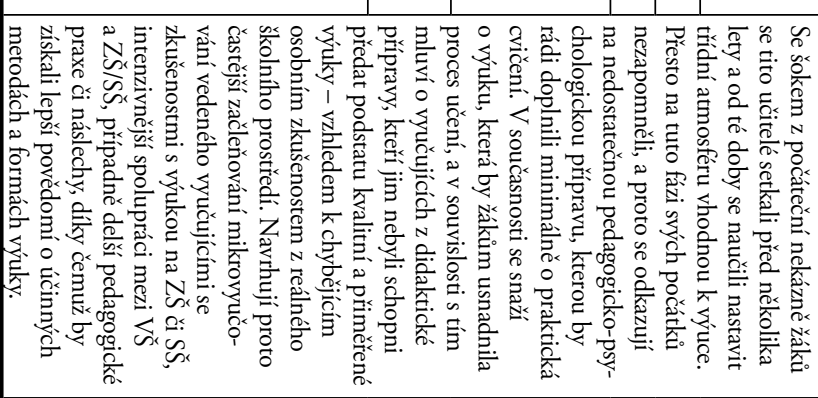 } & \multicolumn{3}{|c|}{ 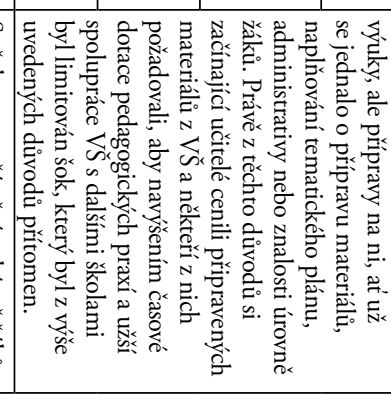 } \\
\hline
\end{tabular}




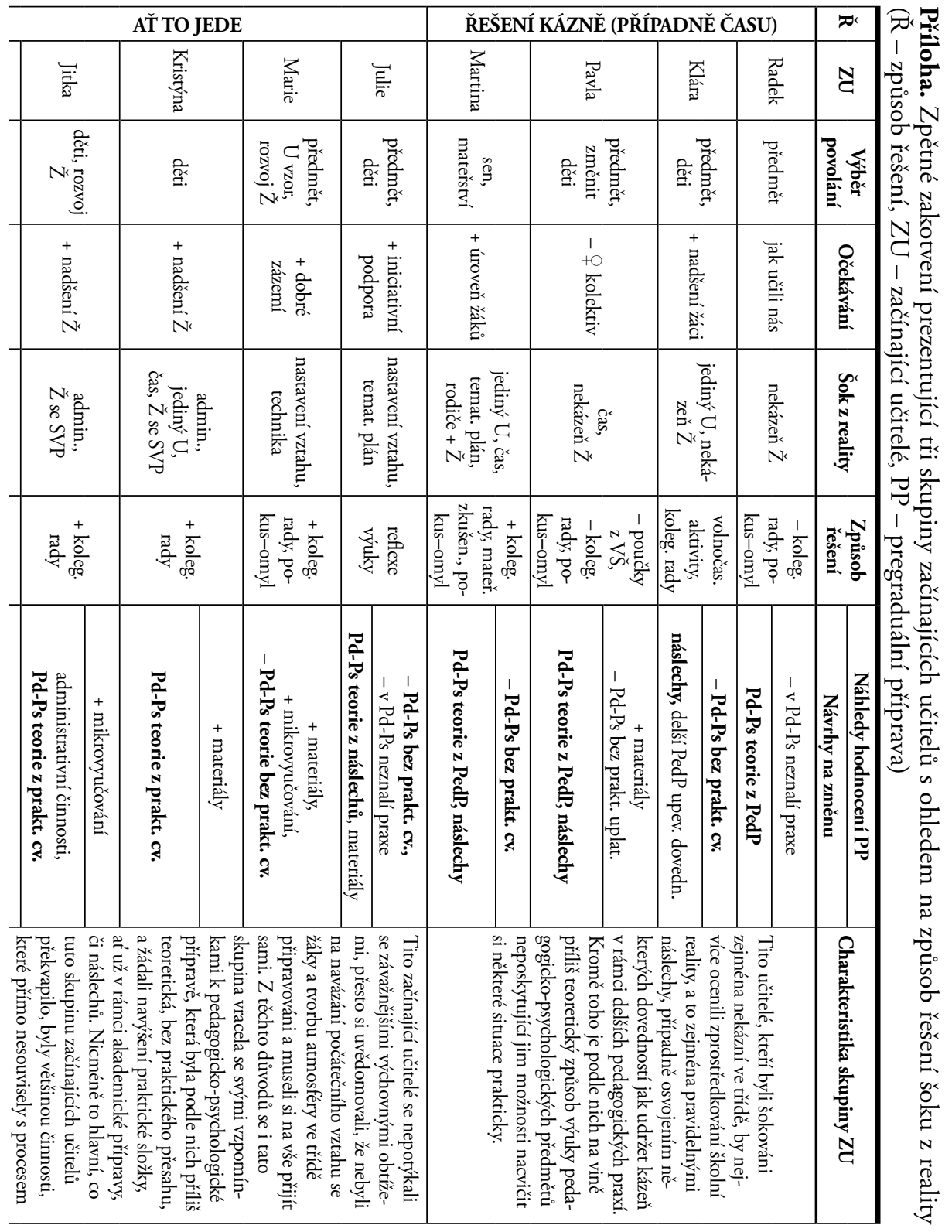


Rajsiglová, I., Príbylová, K.

\begin{tabular}{|c|c|c|c|c|c|c|c|c|c|c|c|c|c|}
\hline \multicolumn{11}{|c|}{ 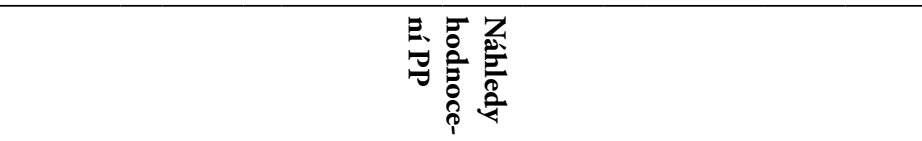 } & \multicolumn{3}{|c|}{ 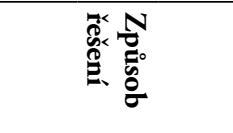 } \\
\hline 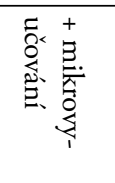 & 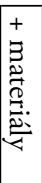 & 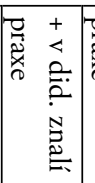 & 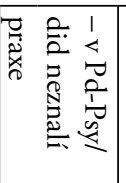 & 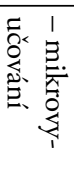 & \multicolumn{3}{|c|}{ 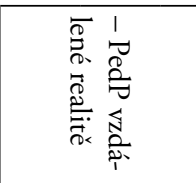 } & 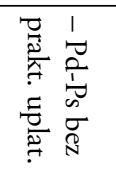 & \multicolumn{2}{|c|}{ 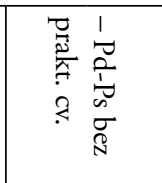 } & 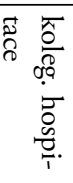 & 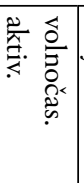 & 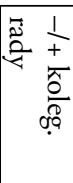 \\
\hline \multicolumn{3}{|c|}{ ․․․ } & \multicolumn{8}{|c|}{ 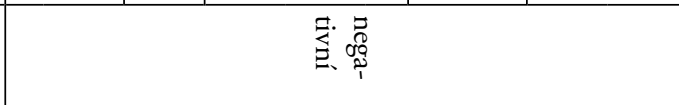 } & \multirow{2}{*}{ 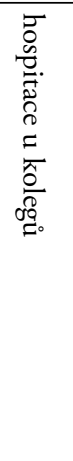 } & \multirow{2}{*}{ 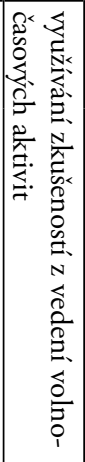 } & \multirow{2}{*}{ 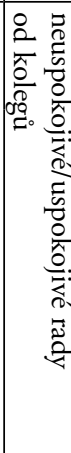 } \\
\hline 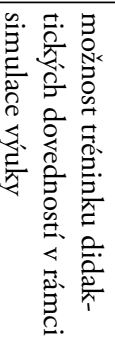 & 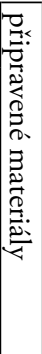 & 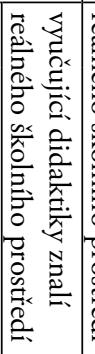 & 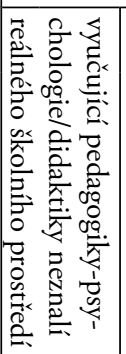 & 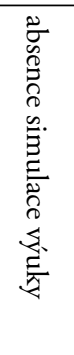 & \multicolumn{3}{|c|}{ 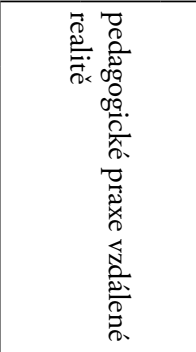 } & 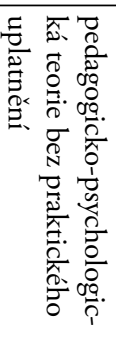 & \multicolumn{2}{|c|}{ 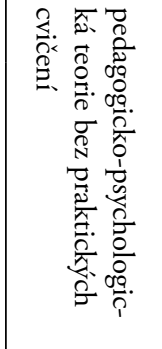 } & & & \\
\hline & 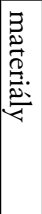 & 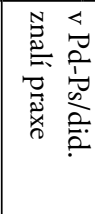 & 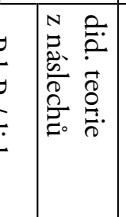 & 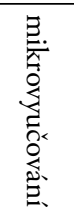 & 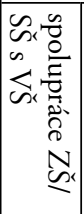 & 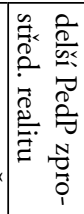 & $\frac{\mathscr{c}}{\overparen{\partial}}$ & 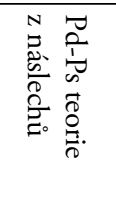 & 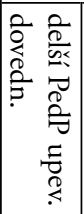 & 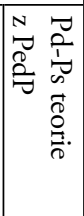 & 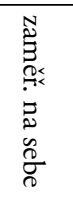 & 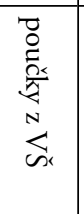 & 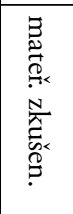 \\
\hline & 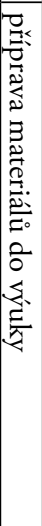 & 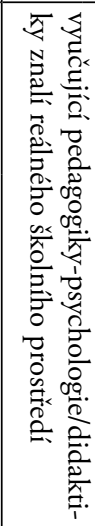 & 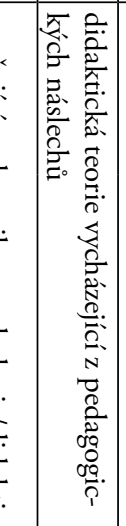 & 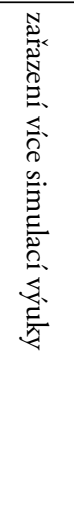 & 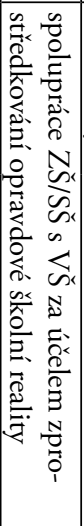 & 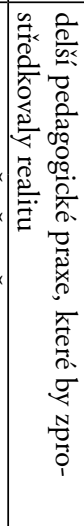 & 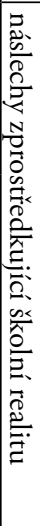 & 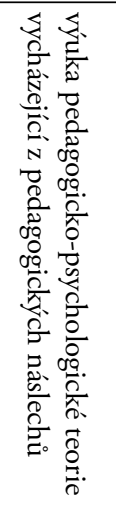 & 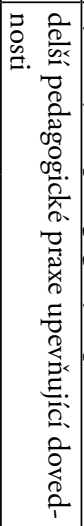 & 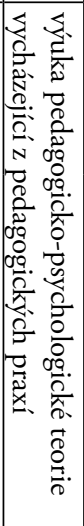 & 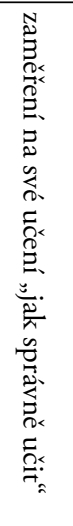 & 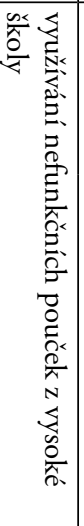 & 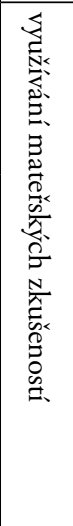 \\
\hline
\end{tabular}




\begin{tabular}{|c|c|c|c|c|c|c|c|c|c|c|c|c|c|c|c|c|c|}
\hline & & $\stackrel{N}{\Xi}$ & 0 & & & & & & 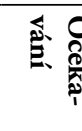 & & & & 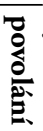 & $\underset{\substack{\alpha \\
g}}{\sum_{0}}$ & & 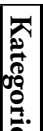 & 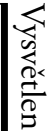 \\
\hline 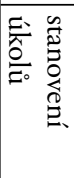 & 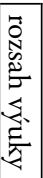 & 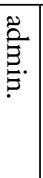 & 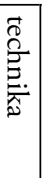 & 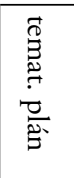 & $\overbrace{<}^{<}$ & 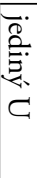 & 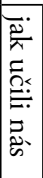 & 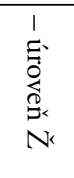 & 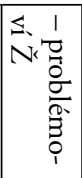 & 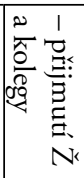 & 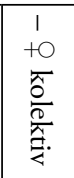 & $\stackrel{\mathscr{D}}{\Xi}$ & 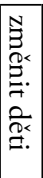 & $\begin{array}{l}\stackrel{\partial}{\partial<} \\
\stackrel{a}{a} . \\
\end{array}$ & 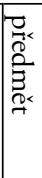 & 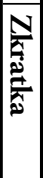 & $\begin{array}{l}\frac{\overrightarrow{0}}{\pi} \\
\vec{D} \\
\stackrel{0}{E}\end{array}$ \\
\hline 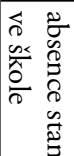 & 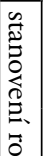 & 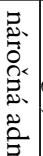 & 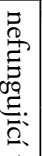 & 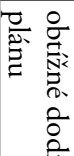 & 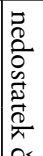 & 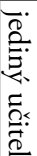 & 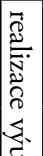 & & 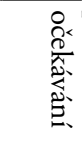 & 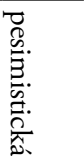 & & 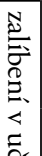 & 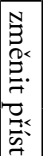 & 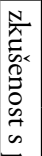 & 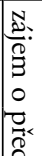 & 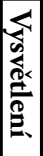 & $\begin{array}{l}\sigma \\
< \\
\sigma \\
\end{array}$ \\
\hline 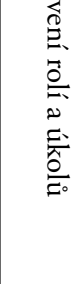 & 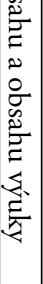 & 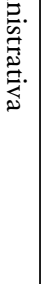 & 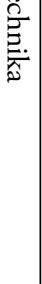 & 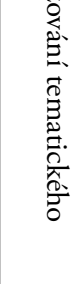 & 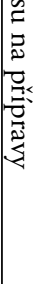 & 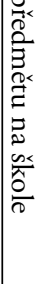 & 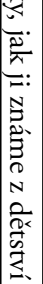 & 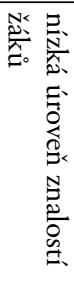 & 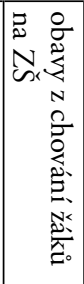 & 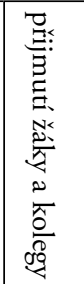 & 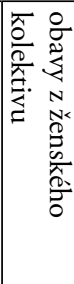 & $\begin{array}{l}\frac{\overrightarrow{0}}{2} \\
\frac{n}{2} \\
0 \\
0 \\
0 \\
0 \\
\overrightarrow{0} \\
0 . \\
0 .\end{array}$ & 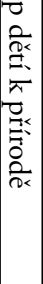 & 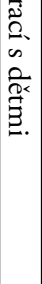 & $\underset{\sim}{\vec{\alpha}<}$ & & \\
\hline 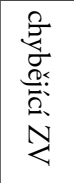 & 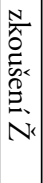 & 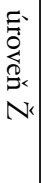 & & $\begin{array}{l}\text { Nk } \\
\infty \\
\infty \\
\infty \\
\infty\end{array}$ & $\begin{array}{l}\vec{\partial} \\
\partial \\
\hat{\partial}_{<} \\
0 \\
+ \\
N_{k}\end{array}$ & 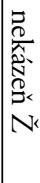 & & 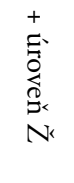 & 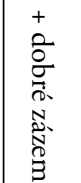 & 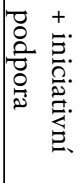 & 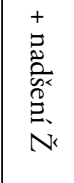 & 营 & & 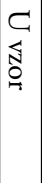 & 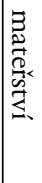 & 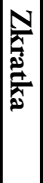 & \\
\hline 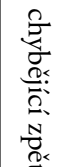 & 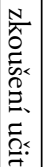 & 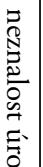 & & 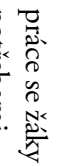 & 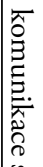 & 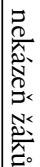 & & & 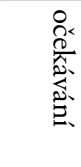 & 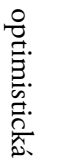 & & 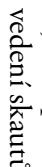 & 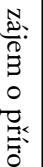 & 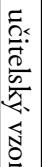 & 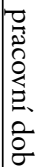 & 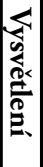 & \\
\hline 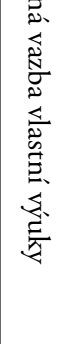 & 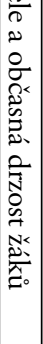 & 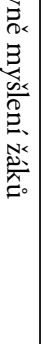 & & 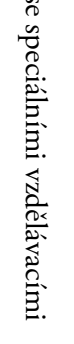 & 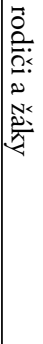 & & & 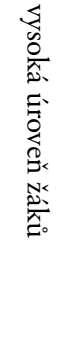 & 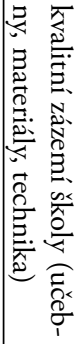 & 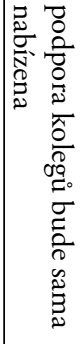 & 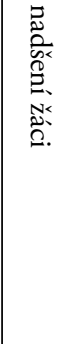 & & 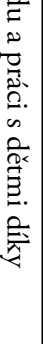 & 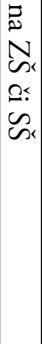 & 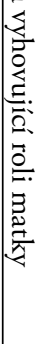 & & \\
\hline
\end{tabular}

